Deflagration in Stainless Steel Storage

Containers Containing Plutonium Dioxide

P. D. Kleinschmidt 



\section{DISCLAIMER}

This report was prepared as an account of work sponsored by an agency of the United States Government. Neither the United States Government nor any agency thereof, nor any of their employees, makes any warranty, express or implied, or assumes any legal liability or responsibility for the accuracy, completeness, or usefulness of any information, apparatus, product, or process disclosed, or represents that its use would not infringe privately owned rights. Reference herein to any specific commercial product, process, or service by trade name, trademark, manufacturer, or otherwise does not necessarily constitute or imply its endorsement, recommendation, or favoring by the United States Government or any agency thereof. The views and opinions of authors expressed herein do not necessarily state or reflect those of the United States Government or any agency thereof. 


\title{
DEFLAGRATION IN STAINLESS STEEL STORAGE CONTAINERS CONTAINING PLUTONIUM DIOXIDE
}

by

\author{
P. D. Kleinschmidt
}

\begin{abstract}
Detonation of hydrogen and oxygen in stainless steel storage containers produces maximum pressures of 68.5 psia and $426.7 \mathrm{psia}$. The cylinders contain $3000 \mathrm{~g}$ of $\mathrm{PuO}_{2}$ with $0.05 \mathrm{wt} \%$ and $0.5 \mathrm{wt} \%$ water respectively. The hydrogen and oxygen are produced by the alpha decomposition of the water. Work Performed for Savannah River Site
\end{abstract}

\section{INTRODUCTION}

Evidence [1] indicates that the reaction:

$$
x \mathrm{H}_{2} \mathrm{O}(\mathrm{ads})+\mathrm{PuO}_{2}(\mathrm{~s})=\mathrm{xH}_{2}(\mathrm{~g})+\mathrm{PuO}_{2+\mathrm{x}}(\mathrm{s})
$$

occurs when water is adsorbed on plutonia. This study will look at the worst case scenario when all the water adsorbed on the plutonia is decomposed according to the reaction where:

$$
\mathrm{H}_{2} \mathrm{O}(\text { ads })+\text { particle }=\mathrm{H}_{2}(\mathrm{~g})+1 / 2 \mathrm{O}_{2}(\mathrm{~g})
$$

The maximum pressures obtained after combusting $\mathrm{H}_{2}$ and $\mathrm{O}_{2}$ will be calculated for the cases of $0.05 \mathrm{wt} \%$ and $0.5 \mathrm{wt} \%$ water adsorbed on the oxide.

The proposed storage container [2] is a stainless steel cylinder (material container) with outer dimensions of 4.50 inches $O D$ and 8.98 inches height and inner dimensions 4.37 inches ID by 8.85 inches height. The material container is contained in the primary containment vessel, the outer dimensions of which are 5.00 inches $\mathrm{OD}$ and 9.63 inches in height. The interior dimensions are 4.87 inches ID and 9.50 inches in height. The interior volume of the primary containment vessel is $2900 \mathrm{~cm}^{3}$. The volume occupied by the walls of the material container is $165 \mathrm{~cm}^{3}$ and the volume occupied by $3000 \mathrm{~g}$ of solid oxide $\left(\mathrm{PuO}_{2}\right)$ with a theoretical density of $11.46 \mathrm{gm} / \mathrm{cm}^{3}$ [3] is $261 \mathrm{~cm}^{3}$. This gives a free volume of $2474 \mathrm{~cm}^{3}$. It is assumed that the material container is breached so that the gas can occupy this free volume in the material container and the primary containment vessel. The density of the powder is assumed to be $2 \mathrm{gm} / \mathrm{cm}^{3}$. The empty volume above the oxide is $1235 \mathrm{~cm}^{3}$. It is assumed that deflagration will occur in this upper volume. Deflagration is defined to be a flame propagated at subsonic speeds from the ignition site. 


\section{CALCUlations}

A total of 0.08326 moles of $\mathrm{H}_{2}$ is produced from a sample with $0.05 \mathrm{wt} \%$ adsorbed water. Ten times this amount will be produced from the $0.5 \mathrm{wt} \%$ sample. In the 0.05 wt \% case $\mathrm{H}_{2}$ occupies $43.5 \%$ of the volume and in the $0.5 \mathrm{wt} \%$ case the volume $\%$ of $\mathrm{H}_{2}$ is $63.3 \%$. In addition to $\mathrm{H}_{2}$ and $\mathrm{O}_{2}, 500$ torr of $\mathrm{He}$ is added to both the primary containment vessel and to the material container. Both of the concentrations of $\mathrm{H}_{2}$ are within the flammability limits 4.0 to $76.0 \mathrm{vol} \%$ [4]. Oxygen concentrations are $22 \%$ for the " $0.05 \mathrm{wt} \% "$ case and $32 \%$ for the $0.5 \mathrm{wt} \%$ case. The maximum flammability limit is not explicitly stated in Zalosh [4], but it is assumed to be greater than $32 \%$.

A mixture of $\mathrm{H}_{2}$ and $\mathrm{O}_{2}$ requires $0.02 \mathrm{~mJ}$ [4] of energy to ignite it. The ignition source is heat produced by the laser used to drill a hole in the primary containment vessel for gas sampling. The dimensions of the drilled hole are 0.010 inch diameter by 0.028 inches in depth [5]. The energy contained in the molten steel is 0.33 joules [6], which is sufficient to ignite the mixture. The thermodynamic properties of $\mathrm{Fe}$ were used as a stand-in for stainless steel.

The peak pressure is calculated from the relation [4]:

$$
P_{m} / P_{o}=n_{b} T_{b} / n_{o} T_{o}
$$

where

$P_{m}=$ peak pressure

$\mathrm{P}_{\mathrm{O}}=$ initial pressure

$\mathrm{n}_{\mathrm{b}}=$ number of moles of gas after combustion

$\mathrm{n}_{\mathrm{o}}=$ number of moles of gas before combustion

$\mathrm{T}_{\mathrm{b}}=$ adiabatic flame temperature

$\mathrm{T}_{\mathbf{O}}=$ initial temperature 
Table. Calculated Peak Pressure from Deflagration

\begin{tabular}{|c|c|c|}
\hline Water loading & $0.05 \%$ & $0.5 \%$ \\
\hline n reactant & 0.0955 moles & 0.6567 moles \\
\hline n product & 0.0433 moles & 0.2410 moles \\
\hline $\mathrm{T}_{\mathrm{b}}$ & $2100 \mathrm{~K}$ & $1800 \mathrm{~K}$ \\
\hline $\mathrm{P}_{\mathrm{o}}$ & $21.4 \mathrm{psia}$ & $191.2 \mathrm{psia}$ \\
\hline $\mathrm{P}_{\mathrm{m}}$ & $68.5 \mathrm{psia}$ & $426.7 \mathrm{psia}$ \\
\hline
\end{tabular}

\section{CONCLUSIONS}

There is sufficient energy in the ignition source to cause a deflagration of the $\mathrm{H}_{2} / \mathrm{O}_{2} / \mathrm{He}$ mixture. The pressures in the primary containment vessel are not sufficient to rupture it. The burst pressure is 2000 psia [7].

\section{REFERENCES}

1. Quarterly Status Report, April I - June 30, 1995, The Nuclear Materials Packaging and Repackaging Project and The Vault Work-Off Project. Los Alamos National Laboratory, July 1995 , N. A. Rink editor.

2. Stainless Steel Storage Containers for TA-55 Vault Repackaging, Los Alamos National Laboratory Nuclear Materials Technology Division Drawing 26Y-203051, 10/21/93.

3. Handbook of Chemistry and Physics, 69th Ed., 1989, CRC Press, Cleveland, Ohio.

4. R. G. Zalosh, in SFPE Handbook of Fire Protection Engineering, Sect. 3 Chap. 16 Explosion Protection, 2nd Ed., P. J. DiNenno et al eds., National Fire Protection Association, Quincy, MA 02269-9101.

5. D. J. Lujan, Los Alamos National Laboratory, private communication, December 1995.

6. Thermodynamic Properties of Individual Substances, L. V. Gurvitch, I. V. Veyts and C. B. Alcock eds. 4th ed. 1989, Hemisphere Publishing Corporation, New York, New York.

7. D. Horrell, Los Alamos National Laboratory, private communication, December 1995. 

